\title{
Unplanned Subject Visit Description
}

National Cancer Institute

\section{Source}

National Cancer Institute. Unplanned Subject Visit Description. NCI Thesaurus. Code C88009.

An account or record of an unexpected subject visit. 